STREETS, BEDROOMS, AND PATIOS 


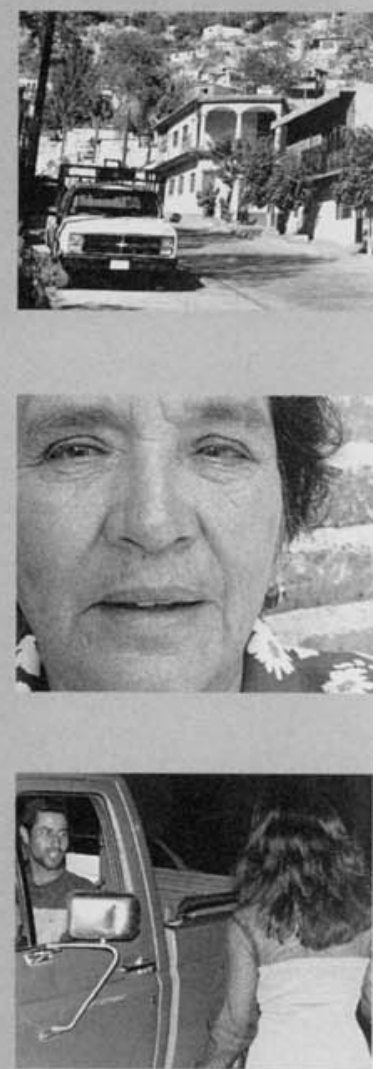

$\rightarrow \begin{aligned} & \text { University of Texas Press } \\ & \text { Austin }\end{aligned}$
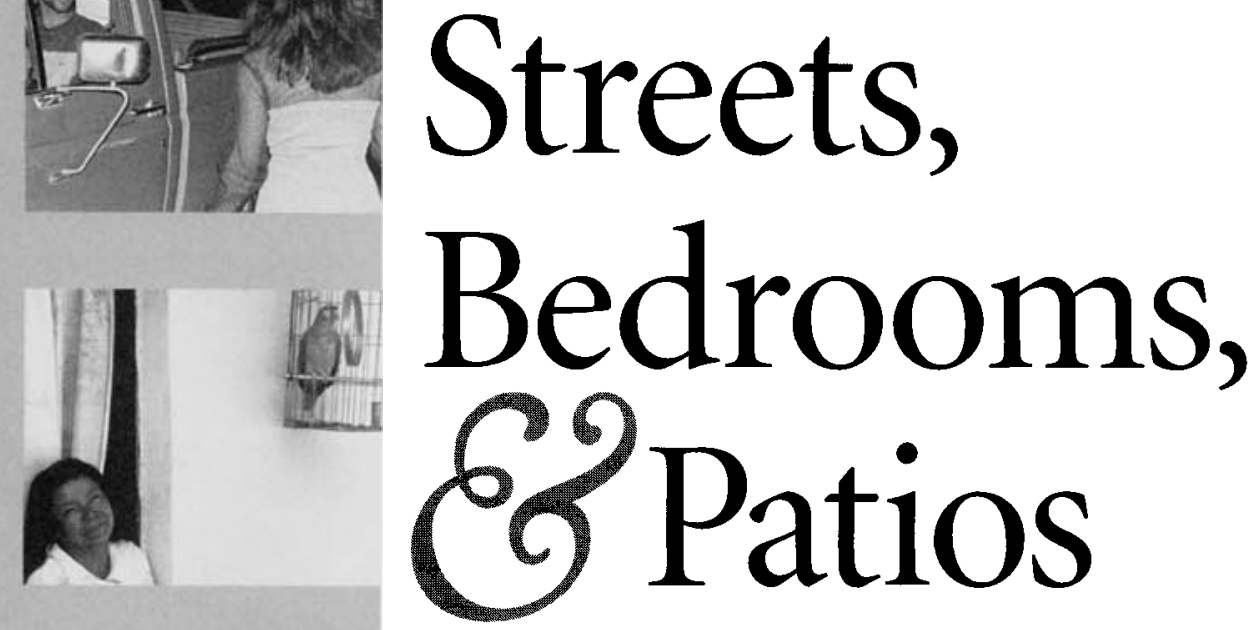

The Ordinariness of Diversity in Urban Oaxaca 
Ethnographic

\section{Portraits of}

the Urban Poor,

Transvestites,

Discapacitados,

and Other

Popular Cultures
MICHAEL JAMES HIGGINS AND TANYA L. COEN

With the Editorial Assistance of Marsha Moore-Jazayeri 
Copyright $\odot 2000$ by the University of Texas Press

All rights reserved

Printed in the United States of America

First edition, 2000

Requests for permission to reproduce material from this work should be sent to Permissions, University of Texas Press, Box 7819, Austin, TX 78713-7819.

(@) The paper used in this book meets the minimum requirements of ANSI/NISO Z39.48-1992 (R1997) (Permanence of Paper).

Higgins, Michael James.

Streets, bedrooms, and patios : the ordinariness of diversity in urban Oaxaca : ethnographic portraits of street kids, urban poor, transvestites, discapacitados, and other popular cultures / Michael James Higgins and Tanya L. Coen ; with the editorial assistance of Marsha Moore-Jazayeri.

p. $\quad \mathrm{cm}$.

Includes bibliographical references and index.

ISBN 0-292-73133-7 (cl.: acid-free paper) — ISBN 0-292-73134-5 (pbk. : acid-free paper)

1. Oaxaca de Juárez (Mexico) - Social conditions. 2. Social groups-Mexico-Oaxaca de Juárez.3. Poor-Mexico-Oaxaca de Juárez. 4. Gays-Mexico—Oaxaca de Juárez. I. Coen, Tanya L. (Tanya Leigh) II. Title.

HN120.018 H53 2000

$306^{\prime} .0972^{\prime} 74-\mathrm{dc21}$ 99-056420 
We would like to dedicate this book

to the memories of:

DOÑA MARÍA ELENA DE SOSA

GUADALUPE MUSALEM

MARTIN DISKIN

- Three very strong spirits in the diversity of urban Oaxaca.

Presente! 
This page intentionally left blank 